\title{
A krónikus myeloid leukaemia korszerú diagnosztikája és kezelése
}

\author{
Demeter Judit dr. ${ }^{1}$ - Poros Anna dr. ${ }^{4}$ - Bödör Csaba dr. ${ }^{2}$ \\ Horváth Laura dr. ${ }^{3}$. Masszi Tamás dr. $^{3}$ \\ Semmelweis Egyetem, Általános Orvostudományi Kar, ${ }^{1}$ I. Belgyógyászati Klinika, \\ ${ }^{2}$ I. Patológiai és Kísérleti Rákkutató Intézet, ${ }^{3}$ III. Belgyógyászati Klinika, Budapest \\ ${ }^{4}$ Magyar Honvédség Egészségügyi Központ, Budapest
}

\begin{abstract}
A krónikus myeloid leukaemia klonális myeloproliferativ betegség, amelyben a haemopoeticus őssejt malignus transzformációja következik be a 9-es és a 22-es kromoszóma hosszú karjai közötti reciprok transzlokációból származó BCR-ABLl fúziós gén által eredményezett konstitutívan aktivált tirozinkináz aktivitásának köszönhetően. A korábbi kezelési lehetőségek ellenére a progresszív betegség kezelésében új távlatokat nyitott a BCR-ABLl fúziós fehérjét gátló tirozinkináz-gátló készítmények felfedezése. A terápiás siker megítélését ennek megfelelően a kezelés mellett elért molekuláris válasz mélysége határozza meg. Jelenleg hazánkban már három tirozinkináz-gátló készítmény elérhető a krónikus myeloid leukaemia kezelésére. Szakmai irányelvünk összefoglalja a krónikus myeloid leukaemia korszerü kezelésének Magyarországon aktuális szempontjait, valamint az azok mellett szükséges terápiás válasz mélységét. Orv. Hetil., 2016, 157(37), 1459-1468.
\end{abstract}

Kulcsszavak: krónikus myeloid leukaemia, BCR-ABL tirozinkináz, szakmai irányelv, Magyarország

\section{Chronic myelogenous leukemia: diagnosis and treatment}

\begin{abstract}
Chronic myelogenous leukemia is a clonal myeloproliferative neoplasm caused by reciprocal translocation involving chromosomes 9 and 22 resulting in the expression of a constitutively activated BCR-ABLl tyrosine kinase that leads to the malignant transformation of the hematopoietic stem cells. The condition was previously known as a relentlessly progressive disease, but the treatment was revolutionalized by the efficacy of tyrosine kinase inhibitors. Therapeutic success is thus currently determined by the depth of molecular response achieved on therapy. Multiple tyrosine kinase agents are available even for the first line treatment. This guideline summarizes current focal points of the treatment of chronic myelogenous leukemia specific to Hungary and provides definitions for optimal molecular responses in this condition.
\end{abstract}

Keywords: chronic myelogenous leukemia, BCR-ABL tyrosine kinase, practice guideline, Hungary

Demeter, J., Poros, A., Bödör, Cs., Horváth, L., Masszi, T. [Chronic myelogenous leukemia: diagnosis and treatment]. Orv. Hetil., 2016, 157(37), 1459-1468.

(Beérkezett: 2016. május 15.; elfogadva: 2016. június 30.)

\section{Rövidítések}

ALL = akut lymphoid leukaemia; allo-HSCT = allogén haemopoeticus őssejtátültetés; $\mathrm{AP}=$ akcelerált fázis; Ara-C = citozinarabinozid; $\mathrm{BP}=$ blasztos fázis; $\mathrm{CCA}=$ klonális citogenetikai eltérések; $\mathrm{CCyR}=$ komplett citogenetikai remisszió; $\mathrm{CHR}=$ komplett hematológiai válasz; $\mathrm{CML}=$ krónikus myeloid leukaemia; $\mathrm{CyR}=$ citogenetikai válasz; $\mathrm{EBMT}=$ European Society for Bone Marrow Transplantation; ELN = European Leukemia Net; FISH = fluoreszcens in situ hibridizáció;
HCT-CI = hematopoietic cell transplant comorbidity index; HSCT = haemopoeticus össejt-transzplantáció; $\mathrm{kDA}=$ kilodalton; $\mathrm{MMR}=$ major molekuláris válasz; $\mathrm{MR}=$ molekuláris válasz; $\mathrm{NA}=$ nem alkalmazható $; \mathrm{OEP}=$ Országos Egészségbiztosítási Pénztár; $\mathrm{PCR}=$ polimeráz láncreakció; $\mathrm{Ph}=$ Philadelphia; RIC $=$ redukált intenzitású kondicionálás; RT-PCR = reverz transzkripciós polimeráz láncreakció; TKI = tirozinkináz-gátló; $\mathrm{TSH}=$ thyroideastimuláló hormon 


\section{Definíció}

A krónikus myeloid leukaemia (CML) olyan klonális myeloproliferativ betegség, amelyben a haemopoeticus őssejt malignus transzformációja következik be. A kiváltásában a 9-es és a 22-es kromoszóma hosszú karjai közötti reciprok transzlokációból származó BCR-ABLl fúziós gén által eredményezett konstitutívan aktivált tirozinkináz áll. CML-nek tehát csak az a betegség nevezhető, ahol a transzlokáció eredményeként létrejött Philadelphia $(\mathrm{Ph})$ kromoszóma vagy a BCR-ABLl fúziós gén kimutatható [1].

\section{Epidemiológia}

Incidencia: 1,0-1,5/100 000 lakos/év. Prevalencia: ennek körülbelül a 4-szerese, amely az elmúlt években meredeken emelkedett a tirozinkináz-gátló (TKI) kezelés bevezetésével elért kezelési eredményeknek (túléléshoszszabbodás) köszönhetően. Életkor: medián 60-65 év, vagyis középkortól felfelé előfordulása gyakoribb (a betegek mintegy negyede 60 év feletti), gyerekkorban csak kivételesen fordul elő. Nem: valamivel (1,2-1,3-szer) több a férfi, mint a nói beteg [1].

\section{Klinikai tünetek}

A betegség természetes lefolyása három szakaszból áll, és a klinikai tüneteket ezek a szakaszok határozzák meg. A krónikus fázisban a betegek 30-40\%-a tünetmentes vagy tünetszegény. Enyhe általános tünetek, mint fáradékonyság, kisfokú fogyás és/vagy étvágytalanság jelentkezhetnek. Különböző mértékű splenomegalia 30-80\%-ban észlelhető, amely bal bordaív alatti fájdalmat okozhat. Hepatomegalia ritkább és kevésbé kifejezett. Nagyon nagy fehérvérsejtszám esetén $\left(250-300 \times 10^{9} / \mathrm{L}\right.$ felett $)$ hiperviszkozitás tünetei is jelentkezhetnek. Akcelerált fázisban jellemzőek a láz, éjszakai izzadás, fogyás és progresszív splenomegalia. Gyakori a mérsékelt anaemia. A blasztos fázis morfológiailag hasonlít az akut leukaemiához, és a fenti tünetek mellett a betegen az akut leukaemiára jellemző granulo- és thrombocytopeniára visszavezethetô infekciós és vérzéses jelek is fellépnek. A CML-t az esetek $85 \%$-ában a krónikus fázisban ismerik fel.

\section{Laboratóriumi diagnózis}

\section{Citogenetikai és molekuláris genetikai eltérések - diagnosztikus kritérium}

A konvencionális citogenetikával a Philadelphia $(\mathrm{Ph})$ kromoszóma, a fluoreszcens in situ hibridizációval (FISH), illetve a reverz transzkripciós polimeráz láncreakcióval (RT-PCR) a BCR-ABLl fúziós gén jelenléte igazolható [1].

\section{Differenciáldiagnózis}

Az egyéb idült myeloproliferativ betegségektől a Ph kromoszóma, illetve a BCR-ABLl fúziós gén jelenléte biztosítja az elkülönítést. Ezek kimutatása diagnosztikus értékű. A foóleg időskorban gyakori Ph-pozitív akut lymphoid leukaemiától (ALL) az anamnézis, a kórlefolyás és az eltérő molekulatömegü (ALL-ben 190 kilodalton [kDa], a CML-ben $210 \mathrm{kDa}$, a ritka neutrofil leukaemiában $230 \mathrm{kDa}$ ) BCR-ABLl fúziós fehérje különíti el.

\section{A betegség stádiumai}

A stádium megállapítása az Európai Leukémia Net (ELN) szakértői által megalkotott fázisbesorolás szerint történik, ennek megfelelően megkülönböztetünk krónikus fázisú $(\mathrm{CP})$, akcelerált fázisú $(\mathrm{AP})$ és blasztos fázisú (BP) betegséget (1. táblázat).

Morfológiailag az esetek körülbelül 70\%-ában a blasztok myeloid típusúak, a többi esetben lymphoid eredetúek. A blasztos fázis típusának megállapításához citokémiai és/vagy immunfenotípus-analízis szükséges, gyakori a myeloid és lymphoid sejtfelszíni antigének koexpressziója [2].

\section{Kezelés}

\section{Általános elvek}

A kezelés elsődleges célja: teljes gyógyulás, teljes citogenetikai remisszió, szignifikáns molekuláris válasz. Másodlagos célok: hematológiai és citogenetikai válasz, tünetmentesség, progresszió megakadályozása. A kezelést a diagnózis felállításakor azonnal meg kell kezdeni. Minél rövidebb idő óta áll fenn a betegség, annál nagyobb a valószínúsége, hogy a beteg rendelkezik még kellő mennyiségű normális haemopoeticus őssejttel. Ez biztosítja azt, hogy a kóros őssejt visszaszorítására szolgáló kezelés után a csontvelő megteljék normális haemopoeticus progenitorokkal.

1. táblázat $\mid$ A CML akcelerált és blasztos fázisának kritériumai [2]

\begin{tabular}{l}
\hline Akcelerált fázis \\
\hline - Blaszt $15-29 \%$ csontvelőben vagy periférián; vagy blaszt + \\
promyelocyta a csontvelőben vagy a periférián $>30 \%$, de a \\
blasztarány $30 \%$ alatti. \\
- Perifériás vérben bazofil $>20 \%$. \\
- Terápiától független perzisztáló thrombocytopenia \\
$\quad\left(<100 \times 10^{9} / \mathrm{L}\right)$. \\
- Klonális citogenetikai evolúció/klonális kromoszómaeltérések \\
$\quad(\mathrm{CCA})$ kialakulása a $\mathrm{Ph}+$ sejtekben, a kezelés során $(\mathrm{CCA} / \mathrm{Ph}+)$. \\
\hline Blasztos fázis \\
\hline - Legalább $30 \%$ blaszt a periférián vagy a csontvelóben. \\
- Extramedulláris blasztos proliferáció.
\end{tabular}

$\mathrm{CCA}=$ klonális kromoszómaeltérések; $\mathrm{CML}=$ krónikus myeloid leukaemia; $\mathrm{Ph}+=$ Philadelphia-pozitív. 


\section{Elsö ponalban}

Imatinib, nilotinib vagy dasatinib.

Úgynevezett „figyelmeztető jelek (nagy kockázatú betegség, klonális kromoszómaeltérés a Ph+ sejtekben" esetén a beteg és testvéreinek HLA-tipizálása.

Második vonalban

Intolerancia: TKI-váltás.

Imantinibterápiás kudarc: TKI-váltás, a beteg és testvéreinek

HLA-tipizálása

Nilotinib- vagy dasatinibkezelés kudarca: TKI-váltás és a család

HLA-tipizálása, családi donor hiánya esetén idegen donor keresése.

Az allo-HSCT mérlegelése.

Harmadik vonalban

Kettő második generációs TKI-val terápiás kudarc és/vagy intolerancia: TKI-váltás és allo-HSCT vagy ponatinib egyedi méltányossági kérelem alapján.

Bármely vonalban T315I esetén

Ponatinib és allo-HSCT.

allo-HSCT = allogén haemopoeticus őssejtátültetés; HLA = humán leukocytaantigén; $\mathrm{Ph}+=$ Philadelphia-pozitív; TKI = tirozinkináz-gátló.

3. táblázat |Kezelési ajánlás akcelerált vagy blasztos fázisban [2]

AP/BP diagnóziskor (TKI-naiv betegek)

Imatinib napi $2 \times 400 \mathrm{mg}$ vagy dasatinib napi $2 \times 70 \mathrm{mg}$ vagy napi

$1 \times 140 \mathrm{mg}$.

Össejtdonor-keresés.

A fentieket követően allo-HSCT javasolt minden blasztos fázisú betegben, illetve optimális választ el nem érő AP esetén.

$A P / B P$, amely a TKI-pal kezelt krónikus fázisból alakult $k i$

Korábban még nem kapott TKI (T315I-mutáció esetén ponatinib), majd allo-HSCT.

A transzplantációt megelőzően sokszor kemoterápia szükséges a transzplantációra alkalmas állapot eléréséhez fóképpen myeloid blasztos fázisban.

allo-HSCT = allogén haemopoeticus őssejtátültetés; $\mathrm{AP}=$ akcelerál fázis; $\mathrm{BP}=$ blasztos fázis; TKI = tirozinkináz-gátló.

A CML kezelésében a leghatékonyabb gyógyszerek a tirozinkináz-gátló (TKI) szerek csoportjába tartoznak. Az elsőként alkalmazott tirozinkináz-gátlónak, az imatinibnek a CML korábbi standard kezelésével interferonalfa citozin-arabinoziddal (Ara-C) történt összehasonlító, többéves utánkövetéses vizsgálata bebizonyította, hogy az imatinib szignifikánsan hatásosabb mind az össztúlélés, mind a progressziómentes túlélés tekintetében. Az imatinib bevezetését több újabb TKI (nilotinib, dasatinib) felfedezése és engedélyezése követette. A TKI-kezelés kimagasló hatásossága mellett az allogén haemopoeticus őssejt-transzplantáció (HSCT) továbbra is szóba jön a CML kezelésében, mindmáig az egyetlen kezelési mód, amely véglegesen meggyógyíthatja a beteget.

Az ELN szakértői legutoljára 2013-ban foglalták öszsze a CML kezelési elveit, amelyet igen széles konszen-
4. táblázat A k

A krónikus myeloid leukaemia kezelésére adott válasz fokozatai

Komplett hematológiai válasz (CHR, minden paraméternek együttesen kell jelen lennie)

Thrombocytaszám: $<450 \times 10^{9} / \mathrm{L}$.

Fehérvérsejtszám: $<10,0 \times 10^{9} / \mathrm{L}$

Kvalitatív vérkép: nincsenek éretlen granulocyták, bazofil: $<5 \%$.

Lép nem tapintható.

Citogenetikai válasz $(\mathrm{CyR})$

Nincs válasz: $\mathrm{Ph}+$ sejtek száma >95\%.

Minimális válasz: $\mathrm{Ph}+$ sejtek száma 66-95\% közötti.

Minor válasz: Ph+ sejtek száma 36-65\% közötti.

Parciális válasz: $\mathrm{Ph}+$ sejtek száma 1-35\% közötti.

Komplett válasz: $\mathrm{Ph}+$ sejtek száma $0 \%$.

Molekuláris válasz (MR)

MR 3,0 BCR-ABLl ${ }^{\text {IS szint }} \leq 0,1 \%=($ MMR $)$

MR 4,0 BCR-ABL1 ${ }^{\text {IS szint }}<0,01 \%$ *

MR 4,5 BCR-ABLl ${ }^{\text {IS szint }}<0,0032 \%$ * *

MR 5,0 BCR-ABL1 ${ }^{\text {IS szint }}<0,001 \%$ ***

$\mathrm{CHR}=$ komplett hematológiai válasz; $\mathrm{CyR}=$ citogenetikai válasz; $\mathrm{IS}=$ nemzetközi skála; $M M R=$ major molekuláris válasz; $M R=$ molekuláris válasz $; \mathrm{PCR}=$ polimeráz láncreakció $; \mathrm{Ph}+=$ Philadelphia-pozitív

* Vagy nem detektálható BCR-ABL1, legalább 10000 ABL1 kópiaszám mellett.

** Vagy nem detektálható BCR-ABLl, legalább 32500 ABLl kópiaszám mellett.

*** Vagy nem detektálható BCR-ABLl, legalább 100000 ABLl kópiaszám mellett.

zus alapján alkottak meg. Ezért indokolt, hogy Magyarországon is ezen elvek alapján történjék a CML-es betegek kezelése. A kezelési stratégia nagymértékben függ a betegségnek a diagnózis idején észlelt fázisától. A krónikus, illetve az előrehaladottabb fázisok esetén követendő kezelési elveket az ELN ajánlása alapján a 2. és 3. táblázatban tüntettük fel [2-10].

A megfelelő kezelési stratégiához a terápiás válasz szoros nyomon követése szükséges (4. és 5. táblázat). Az optimális terápiás választ mutató betegeknél szignifikánsan jobb túlélésre lehet számítani, és a terápiás válasz mélysége fordítottan arányos a betegség progressziójának kockázatával $[4,5]$.

\section{Kezelésre adott válaszok és azok értékelése}

Bármikor, ha a citogenetikai vagy molekuláris teszt a kategóriákban szereplő értékeket csak kevéssé haladja meg vagy alig van alatta, akkor a teszteket érdemes a protokolltól eltérő, rövidebb időközökben elvégezni. 
5. táblázat |A terápiás válaszok értékelése a krónikus myeloid leukaemia első vonalbeli TKI-kezelése során [2]

\begin{tabular}{|c|c|c|c|}
\hline $\begin{array}{l}\text { Diagnózis megállapításától } \\
\text { eltelt idő }\end{array}$ & Célkitúzés (optimális válasz) & Figyelmeztető jelek & Kudarc \\
\hline 3 hónap & $\begin{array}{l}\text { BCR-ABLl } \leq 10 \% \text { és/vagy } \mathrm{Ph}+ \\
\leq 35 \% \text { (parciális citogenetikai válasz) }\end{array}$ & $\begin{array}{l}\text { BCR-ABLl >10\% és/vagy } \mathrm{Ph}+ \\
36-95 \%\end{array}$ & $\begin{array}{l}\text { Nincs komplett hematológiai } \\
\text { remisszió és/vagy } \mathrm{Ph}+>95 \%\end{array}$ \\
\hline 6 hónap & $\begin{array}{l}\text { BCR-ABLl < } \% \text { és/vagy } \mathrm{Ph}+0 \% \\
\text { (komplett citogenetikai válasz, } \\
\text { CCyR) }\end{array}$ & $\begin{array}{l}\text { BCR-ABLl 1-10\% és/vagy } \mathrm{Ph}+ \\
1-35 \%\end{array}$ & $\begin{array}{l}\text { BCR-ABLl >10\% és/vagy } \mathrm{Ph}+ \\
>35 \%\end{array}$ \\
\hline 12 hónap & BCR-ABLl $\leq 0,1 \%(\mathrm{MMR})$ & BCR-ABLl >0,1-1\% & BCR-ABLl >1\% és/vagy $\mathrm{Ph}+>0$ \\
\hline 12 hónap után bármikor & Stabil MMR vagy mélyebb válasz & $\mathrm{CCA} / \mathrm{Ph}-(-7$, vagy $7 \mathrm{q}-)$ & $\begin{array}{l}\text { A hematológiai vagy citogenetikai } \\
\text { remisszió vagy MMR elveszítése, } \\
\text { mutációk a } \mathrm{Ph}+\text { sejtekben }\end{array}$ \\
\hline
\end{tabular}

$\mathrm{CCA} / \mathrm{Ph}-=$ klonális citogenetikai eltérés a Ph-negatív sejtekben; $\mathrm{CHR}=$ komplett hematológiai válasz, $\mathrm{CCyR}=\mathrm{komplett}$ citogenetikai válasz; $\mathrm{MMR}=$ major molekuláris válasz; PCR = polimeráz láncreakció; Ph+ = Philadelphia-pozitív.

6. táblázat | Javaslat a citogenetikai és molekuláris monitorozásra [2]

\begin{tabular}{|c|c|}
\hline \multirow[t]{3}{*}{ Diagnóziskor } & Kromoszómaanalízis (sávozás) a csontvelőből, metafázis-citogenetika. \\
\hline & FISH Ph-negativitás esetén (variánsok, rejtett transzlokációk). \\
\hline & Kvalitatív PCR (a transzkriptum típusának megállapítása). \\
\hline A kezelés során & $\begin{array}{l}\text { Kvantitatív real-time PCR a BCR-ABLl transzkriptum mennyiségének meghatározására } 3 \text { havonta az MMR } \\
\text { (BCR-ABLl } \leq 0,1 \%, \mathrm{MR} 3,0 \text { ) eléréséig, majd 3-6 havonta és/vagy kromoszómaanalízis (sávozás) csontvelőból } \\
\text { (legalább } 20 \text { metafázis) 3,6 és } 12 \text { hónapnál a CCyR eléréséig, majd } 12 \text { havonta. Ha a CCyR kialakult, elegendó a } \\
\text { FISH perifériás vérból. Ha megfeleló molekuláris monitorozás rendelkezésre áll, a citogenetikától el lehet } \\
\text { tekinteni! }\end{array}$ \\
\hline Kudarc, progresszió & $\begin{array}{l}\text { RQ-PCR, mutációk vizsgálata (direkt szekvenálás) és kromoszómaanalízis a csontvelőből. Blasztos fázis esetén } \\
\text { áramlási citometria, immunfenotipizálás. }\end{array}$ \\
\hline Figyelmeztető jelek esetén & $\begin{array}{l}\text { Gyakoribb molekuláris és citogenetikai követés. Myelodysplasia vagy a Ph-negatív sejtekben észlelt, a 7-es } \\
\text { kromoszóma érintettségével járó klonális kromoszómaeltérés esetén citogenetikai monitorozás szükséges. }\end{array}$ \\
\hline
\end{tabular}

$\mathrm{CCyR}=$ komplett citogenetikai válasz; FISH = fluoreszcens in situ hibridizáció; MMR = major molekuláris válasz; MR = molekuláris válasz; $\mathrm{PCR}$ = polimeráz láncreakció; $\mathrm{Ph}$ = Philadelphia; RQ-PCR = valós idejű kvantitatív polimeráz láncreakció.

\section{Kezelés krónikus fázisban}

\section{Első vonalbeli kezelés}

Jelenleg javasolt és finanszirozott standard kezelés: imatinib $1 \times 400 \mathrm{mg}$ vagy nilotonib $2 \times 300 \mathrm{mg}$ vagy $1 \times 100 \mathrm{mg}$ dasatinib naponta.

Újonnan diagnosztizált CML-es betegek második generációs TKI-kezelésével rövidebb idő alatt és nagyobb arányban érhetô el komplett citogenetikai válasz, valamint 3 nagyságrendnyi BCR-ABLl kópiaszám-csökkenés is (MMR), mint az első generációs imatinibbel. Ez a betegek progressziómentes túlélésében egyértelmú előnyt jelent. Ezen adatok alapján két második generációs TKI-t, a nilotinibet és a dasatinibet Európában is törzskönyveztek a CML első vonalbeli kezelésére. A két szer közötti választásnál a várható mellékhatások miatt a kísérő betegségeket kell figyelembe venni, ahogy ezt a másodvonalbeli kezelésnél részletezzük [2-10].

\section{A terápiás válasz értékelésébez szükséges teendōk és a kezelés további megválasztása}

A terápiás válasz jó megítéléséhez először is a diagnózis idejében észlelt pontos státusz rögzítése szükséges. A hematológiai és citogenetikai vizsgálatok eredménye alapján állapítható meg a beteg rizikóbeosztása (lásd később), és más, a kezelésnél figyelembe veendő figyelmeztető jelek (p. CCA/Ph+). A TKI-gátló elkezdése után a betegek fizikális státuszát és vérképét sưrúbben (hetente, majd kéthetente, illetve havonta) követjük a hatás, illetve az esetleges mellékhatások gondos megfigyelése céljából. Az első részletesebb ellenőrző pont 3 hónappal a TKI megkezdése után szükséges, ekkorra betegünk optimális esetben teljes hematológiai remisszióban van. A kezelés során a terápiás válasz megítéléséhez szükséges citogenetikai és molekuláris monitorozást a 6. táblázat mutatja [2]. 
A gyógyszer optimális adagolása, illetve a terápiaváltás indoklása a speciális monitorozás mellett az anamnézis, fizikális vizsgálat és a vérkép, kémiai vizsgálatok ütemes elvégzését is igényli.

Az első vonalbeli TKI-kezelés során adott terápiás válaszokat az 5. táblázat mutatja.

A definíciók nemcsak a krónikus fázisban érvényesek, hanem már a diagnóziskor is akcelerált fázisban kezdett első kezelés megítélésére is. Sơt érvényes arra az esetre is, a korábbiaktól eltérően, ha az adott TKI-t ugyan nem elsőként adtuk, de a TKI-váltás csupán intolerancia miatt következett be.

A korábbiakhoz képest lényeges változás, hogy a válasz megítélésében a molekuláris monitorozásnak legalább annyi vagy nagyobb jelentősége van, mint a korábbiakban legkiemelkedőbb jelentőségünek tekintett citogenetikai monitorozásnak.

Változás az is, hogy a terápiás, vagyis az optimális válasz mélyebb és gyorsabb terápiás választ takar. Ezért el is vesztette a jelentőségét a 18. hónapban történő értékelés, hiszen a major molekuláris válasz, vagyis az MR 3,0 már a 12. hónapban feltétel az optimális válaszhoz. Megjegyzendő, hogy az MR 3,0 az eddigi vizsgálatok szerint optimálisnak tekinthető a túlélés szempontjából, de biztos, hogy a TKI-kezelés sikeres felfüggesztése mélyebb molekuláris választ igényel. 12 hónapon túl minden MR 3,0-nál rosszabb BCR-ABLl szint „jelzés értékü", ilyen esetben a teszt havonta ismétlendő a terápiás kudarc kizárása vagy megerősítése érdekében.

Az ELN 2013 ajánlás szakít a szuboptimális válasz fogalmával, helyette a „figyelmeztetés” = „warning” fogalmat használja. Ez a fogalom azt jelenti, hogy vagy a betegség jellege (például magas rizikó), vagy a kapott bizonytalan terápiás válasz gyakoribb monitorozást igényel, vagyis a $B C R-A B L 1$ szint mérése havonta végzendő. Ez lehetővé teszi a gyógyszer és a kezelési stratégia megfelelő időben történő változtatását [2].

Továbbra is érvényes, hogy TKI-páltás elött vizsgálni kell a betegcompliance-t és a gyógyszerkölcsönhatásokat. Mindkét esetben segít a gyógyszerszintmérés elvégzése, ez a vizsgálat az imatinib és a nilotinib esetében lehetséges és hasznos, de hazánkban jelenleg rutinvizsgálatként nem elérhető. Szükséges a mutációanalízis elvégzése a következő TKI megválasztásához. Az életkor és a kísérő betegségek figyelembevételével értékelendő, hogy a tervezett TKI-kezelést a beteg várhatóan hogyan fogja tolerálni. Így például szívbetegség, diabetes mellitus fennállása esetén a nilotinib, tüdőbetegségek esetén a dasatinib adása különösen megfontolandó. Minden TKI-kezelés során igen fontos a QTc-intervallum ismerete, különösen gyógyszeres kezelést igénylő társbetegségek esetén kell gondolnunk a ritmuszavart okozó gyógyszer-interakciók lehetőségére. Bár a krónikus fázisú CML-ben a dasatinib standard napi adagja már több éve nem $140 \mathrm{mg}$, hanem $100 \mathrm{mg}$, és ez a tisztázatlan okú hydrothorax kialakulásának kockázatát egyértelműen csökkentette, de a kontrollra vagy panasszal jelentkező
CML-es beteg fizikális vizsgálata során ennek a szövődménynek a lehetősége is fel kell, hogy vetődjön [11-15].

Összefoglalva: Megfelelő időben történő monitorozásnál optimális válasz esetén a megkezdett TKI folytatandó, figyelmeztetés esetén havonként mért BCR-ABLl szint alakulása dönti el, hogy a beteg válasza optimálisnak vagy kudarcnak tekintendő. Előbbi esetben a megkezdett TKI folytatása, utóbbi esetben a TKI-váltás indikált. Terápiás kudarc esetén TKI-váltás és kezelési stratégia újragondolása, például allogén őssejt-transzplantáció javasolt.

A szerzők az ELN 2013 ajánlását javasolják az OEPfinanszírozási protokoll alapjául, ezzel biztosítva a TKIre adott terápiás válaszoknak megfelelő kezelést.

Az új ELN-s terápiás ajánlásban a lényeges változás a korábbiakhoz képest, hogy az első vonalbeli TKI-kezeléshez már három szer áll rendelkezésre (imatinib, nilotinib, dasatinib). Változás még, hogy számúzte a dózisemelés fogalmát, mégpedig úgy, hogy a kudarc és az optimális válasz közötti köztes válasz esetén a gyakori monitorozás eredményétől teszi függővé a gyógyszer folytatását, illetve TKI-váltást javasol a készítmény dózisának emelése helyett [2-10].

A jelenleg ajánlott kezelési stratégiából sem maradt ki viszont az allogén őssejt-transzplantáció, mint kezelési lehetőség, ezért fontos időben gondoskodni a donor (családi vagy idegen) felkutatásáról.

Családi donorkeresés indokolt:

- diagnóziskor fennálló figyelmeztető jelek (nagy rizikóscore, $\mathrm{CCA} / \mathrm{Ph}+$ );

- TKI intolerancia;

- terápiás kudarc első vonalban adott, első generációs TKI-val.

Idegen donor keresése, ha nincs családi donor:

- terápiás kudarc első vonalban adott második generációs TKI-val (nilotinib, dasatinib);

- T315I mutáció jelenléte;

- AP és BP.

$\mathrm{Az}$ allogén transzplantációt ma leginkább harmadvonalbeli kezelésként ajánlják, indikáció felállításához a fentiek mellett a kockázatokat is figyelembe kell venni (lásd később).

\section{Vizsgálati teendōk és kezelés relapsus esetén}

A jó terápiás válasz elvesztése és/vagy a betegség elörehaladottabb fázisba kerülése (progresszió) a betegség relapsusának tekintendő, amely természetszerúleg terápiás kudarcot jelent.

Terápiás válasz elvesztése: CHR megszünése (2 vizsgálat alapján): mutációkeresés, TKI-váltás vagy HSCT.

CCyR megszünése (2 vizsgálat alapján): mutációkeresés, TKI-váltás vagy HSCT.

$M M R=M R$ 3,0 megszünése: Ha megnő a BCR-ABLl szint, akkor az RQ-PCR havonta ismétlendő. Két alkalommal észlelt emelkedett szint esetén: citogenetika, mutációanalízis szükséges, döntés eredmény szerint. 
A terápiás váltások eredményéról általában legalább 3 hónap kezelési idő után lehet nyilatkozni, kivéve az esetleges hamarabb jelentkező nyilvánvaló hematológiai progressziót.

Kezelés alatt elörehaladottabb fázisba keriulés (progreszszió): TKI-váltás és felkészülés HSCT-re, és HSCT-rizikó-felmérés.

\section{Gyógyszer-intolerancia fogalma}

Gyógyszer-intoleranciáról abban az esetben beszélünk, ha legalább 3-as fokozatú mellékhatás esetén átmeneti dóziscsökkentés vagy a szer átmeneti szüneteltetése nem eredményes, illetve reexpozíció esetén bekövetkező ismétlődése miatt dózisredukció szükséges.

\section{Második vonalbeli kezelés}

\section{Gyógyszeres: tirozinkináz-inbibitor (TKI)-váltás}

TKI-váltás 2. generációs TKI-ra: napi $2 \times 400 \mathrm{mg}$ nilotinibre vagy napi $1 \times 100 \mathrm{mg}$ dasatinibra. A bosutinib 500 $\mathrm{mg} / \mathrm{nap}$ adagban a három fent említett TKI-ra rezisztens vagy intoleráns betegek esetében javallt, finanszírozása egyedi méltányossági kérelem alapján történik.

Indikáció: 1. Első vonalban alkalmazott TKI-val terápiás kudarc. 2. Relapsus (terápiás válasz elvesztése és/ vagy progresszió).

Feltétele: T315I-mutáció hiánya.

T3151-mutáció jelenlétében a fenti TKI-k nem hatásosak, ezért ilyenkor ponatinib adása szükséges. Az Iclusig jelenleg ajánlott kezdő dózisa napi 45 mg. (Dózisoptimalizálási vizsgálatok még mindig folynak a világban.) A ponatinibkezelés során - az eddig ismert TKI-k kö- zül - az érrendszeri szövődmények a leggyakrabban észlelhetők, ezért esetében különösen fontos a beteg vascularis rizikójának felmérése a kezelés megkezdése előtt.

A CML tirozinkináz-gátló kezelését megelőzően azok későbbi esetleges általános cardiovascularis és metabolikus mellékhatásaira tekintettel az alábbi vizsgálatok elvégzése javasolt:

- EKG-regisztrátum, különös tekintettel a súlyozott QT-intervellumra (QTc);

- echokardiográfiás vizsgálat;

- boka-kar index meghatározása, illetve annak perifériás érbetegségre utaló kóros eredménye esetén artériás Doppler-ultrahangvizsgálatok.

Emellett javasolt a kezelés megkezdését megelőzően az éhomi vércukorszint meghatározása, a vérzsírprofil vizsgálata, a thyreoideastimuláló hormon (TSH), pancreaslaesióra utaló enzimszintek (szérumamiláz és -lipáz), összbilirubin mérése.

Kóros éhomi vércukorszint esetén a hemoglobin-A-lc meghatározása, illetve orális glükóztolerancia-teszt is elvégzendő.

A jelzett vizsgálatok a késóbbi mellékhatások megfelelő időben való felismerése céljából a tirozinkináz-gátló kezelés mellett 3 havonta ismétlendők, különös tekintettel azokra az esetekre, amikor kiinduláskor eleve kóros eltérések voltak észlelhetők.

Másodvonalbeli kezelésként melyik második generációs TKI választandó?

Figyelembe veendő tényezők:

1. Kísérő betegségek.

2. Mutáció típusa.

7. táblázat |A terápiás válaszok értékelése a krónikus myeloid leukaemia második vonalbeli TKI-kezelése során, imatinibkezelést követően [2]

\begin{tabular}{|c|c|c|c|}
\hline $\begin{array}{l}\text { Diagnózis megállapításától } \\
\text { eltelt idő }\end{array}$ & Optimális válasz & Figyelmeztető jelek & Kudarc \\
\hline Induláskor & NA & $\begin{array}{l}\text { CHR hiánya vagy elvesztése } \\
\text { imatinibkezelés mellett, vagy CyR } \\
\text { hiánya első vonalbeli TKI-kezelés } \\
\text { mellett, vagy } \\
\text { magas rizikó }\end{array}$ & NA \\
\hline 3 hónap & $\begin{array}{l}\text { BCR-ABLl } \leq 10 \% \text { és/vagy } \mathrm{Ph}+ \\
<65 \%\end{array}$ & $\begin{array}{l}\text { BCR-ABLl >10\% és/vagy Ph+ } \\
65-95 \%\end{array}$ & $\begin{array}{l}\text { Nincs } \mathrm{CHR} \text { vagy } \mathrm{Ph}+>95 \% \text { vagy új } \\
\text { mutációk }\end{array}$ \\
\hline 6 hónap & $\begin{array}{l}\text { BCR-ABLl } \leq 10 \% \text { és/vagy } \mathrm{Ph}+ \\
<35 \%\end{array}$ & $\mathrm{Ph}+36-65 \%$ & $\begin{array}{l}\text { BCR-ABLl >10\% és/vagy } \mathrm{Ph}+ \\
>65 \% \text { és/vagy új mutációk }\end{array}$ \\
\hline 12 hónap & BCR-ABLl <l\% és/vagy Ph+ 0\% & $\begin{array}{l}\text { BCR-ABLl } 1-10 \% \text { és/vagy } \mathrm{Ph}+ \\
1-35 \%\end{array}$ & $\begin{array}{l}\text { BCR-ABLl > } 10 \% \text { és/vagy Ph+ } \\
>35 \% \text { és/vagy új mutációk }\end{array}$ \\
\hline 12 hónap után bármikor & BCR-ABLl $\leq 0,1 \%$ & $\begin{array}{l}\mathrm{CCA} / \mathrm{Ph}-(-7 \text { vagy } 7 \mathrm{q}-) \text { vagy } \\
\mathrm{BCR}-\mathrm{ABLl}>0,1 \%\end{array}$ & $\begin{array}{l}\text { CHR elvesztése vagy CCyR vagy } \\
\text { PCyR elvesztése, új mutációk, } \\
\text { MMR elvesztése* }, \mathrm{CCA} / \mathrm{Ph}+\end{array}$ \\
\hline
\end{tabular}

CCA/Ph+ = klonális citogenetikai eltérés a Ph-pozitív sejtekben; CCA/Ph- = klonális citogenetikai eltérés a Ph-negatív sejtekben; CCyR = komplett citogenetikai válasz; $\mathrm{CHR}=$ komplett hematológiai válasz; $\mathrm{CyR}=$ citogenetikai válasz; $\mathrm{NA}=$ nem alkalmazható; $\mathrm{MMR}=$ major molekuláris válasz; TKI = tirozinkináz-gátló.

*2 egymást követő vizsgálattal megerősítve, ahol az egyik > 1\% BCR-ABLl transzkriptumszintet mutat. 
Nilotinib választandó: szívbetegség, COPD, hypertonia, autoimmun betegség az anamnézisben, bizonyos imatinibrezisztencia-mutációk (V299L, F317L, Q252H).

Dasatinib választandó: diabetes mellitus, máj-pancreas eltérések, emelkedett szérumbilirubin és/vagy szérumlipáz, pancreasbetegség az anamnézisben, bizonyos imatinibrezisztencia-mutációk (E255K/V, Y253H, F359C/V) [11-15].

Az első vonalbeli TKI-kezelésre adott terápiás válasz kritériumától valamelyest eltérnek a második vonalbeli TKI-kezelésre adott terápiás válasz kritériumai (7. táblázat) [2].

A fenti definíció rendszer nilotinibre és dasatinibre készült, és pillanatnyilag átmenetinek tekinthető. Fontos hangsúlyozni, hogy a rendszer kizárólag a terápiás kudarc miatt kezdett másodvonalbeli TKI-kezelésre vonatkozik. Az intolerancia miatt bevezetett másodvonalbeli TKI-kezelésre adott terápiás válasz értékelésénél az első vonalbeli terápiás válasz kritériumait kell figyelembe venni (5. táblázat).

A korábbi ELN-ajánlással ellentétben krónikus fázisban ma már a másodvonalbeli kezelésnek nem része az allogén őssejtátültetés.

\section{Harmadvonalbeli kezelés \\ Gyógyszeres}

Már két TKI-val szembeni terápiás kudarc vagy intolerancia esetén harmadvonalbeli kezelés javasolt. Gyógyszerválasztás: ponatinib vagy az eddig még nem alkalmazott TKI, illetve az allogén őssejtátültetés, ha van megfelelő donor. A ponatinib finanszírozása egyedi méltányossági kérelem alapján történik.

\section{Haemopoeticus ôssejt-transzplantáció}

A ma ismert és használatos kezelések közül csak az allogén őssejtátültetés eredményezhet gyógyulást, de a beavatkozást magas halálozási kockázata szorítja a harmadik terápiás vonalba.

Indikáció:

1. Első és másodvonalban adott két TKI-val terápiás kudarc, legalább két TKI-val szemben intolerancia.

2. TKI-kezelés alatt kialakult előrehaladott betegségfázis.

Az EBMT-score és az allogén össejt-transzplantáció várbató kimenetele közötti összefüggés

Az EBMT score egymástól független rizikótényezőket vesz figyelembe, ezek fennállása alapján az összes pontérték 0-7 között változhat, amely meghatározza a transzplantációt követő túlélést (8. táblázat). A donor és a recipiens HLA-vizsgálati módszerek javulásával a családi és idegen identikus donor közötti különbség inkább csak idősebb recipiensnél lényeges. Az EBMT score megalkotása idejében a transzplantációval kapcsolatos mortalitás még az alacsony rizikópontértéknél is $20 \%$ körüli volt. A transzplantációs technika javulásával ez most
8. táblázat $\mid$ European Group for Blood and Marrow Transplantation (EBMT) score [16]

\begin{tabular}{|c|c|}
\hline Rizikó & Pont \\
\hline \multicolumn{2}{|l|}{ Beteg életkora } \\
\hline$<20$ & 0 \\
\hline $20-40$ & 1 \\
\hline$>40$ & 2 \\
\hline \multicolumn{2}{|l|}{ Betegség stádiuma } \\
\hline Korai & 0 \\
\hline Közepesen előrehaladott & 1 \\
\hline Késői & 2 \\
\hline \multicolumn{2}{|l|}{ Transzplantációig eltelt idő } \\
\hline <12 hó & 0 \\
\hline$>12$ hó & 1 \\
\hline \multicolumn{2}{|l|}{ A donor típusa } \\
\hline HLA-azonos testvér donor & 0 \\
\hline Idegen donor & 1 \\
\hline \multicolumn{2}{|l|}{ Donor-recipiens nemi egyezés } \\
\hline Bármely kombináció, kivéve a lenti & 0 \\
\hline Női donor, férfi recipiens & 1 \\
\hline
\end{tabular}

$10 \%$ alá esett a 2 vagy kevesebb pontértéknél. Ha az összpontszám 5 vagy annál több, akkor az ötéves túlélés valószínúsége most is csak $30-40 \%$. A transzplantáció utáni, nem relapsussal magyarázható mortalitás esélye megjósolható még a hematopoietic cell transplant comorbidity index (HCT-CI, Sorror score) segítségével is [16]. Transzplantáció komorbiditások alapján várható kockázatára vonatkozó pontszámot minden allogén haemopoeticus őssejt-transzplantáció mérlegelésekor ki kell számolni és várható hatását meg kell fontolni [16-19]. A TKI-kezelés érájában úgy tûnik, hogy a II-III. krónikus fázis transzplantációs kimenetele közelebb áll az akcelerált fáziséhoz, mint a blasztos fáziséhoz. Az idők folyamán a transzplantáció kimenetelében szerepet játszó újabb tényezők is felmerültek, mint például a recipiens CMV és Karnofsky-státusza, komorbiditás és egyes citokinek polimorfizmusa. A nagy beteganyagon végzett statisztikai értékelések szerint azonban egyik tényező sem érvénytelenítette a rendszert. Bizonyos az is, hogy a transzplantáció előtti TKI-kezelés nem hat kedvezőtlenül a kimenetelre.

\section{Az allogén össejtátültetés formái}

1. Myeloablativ kondicionálással történő transzplantáció.

2. Redukált intenzitású kondicionálással (RIC) végzett úgynevezett minitranszplantáció a 2-nél nagyobb EBMT-score-t mutató betegeknél jön szóba. A legújabb adatok szerint a krónikus fázisban RIC-vel végzett transzplantációk eredményei nem kedvezőtleneb- 
bek, mint a myeloablativ kondicionálással történt transzplantációké.

Amennyiben az allogén átültetés indikációja a TKI-kezelés során kialakult előrehaladott fázis, akkor az átültetés előtt TKI-váltással, sőt, ha szükséges, TKI + kemoterápiával kell megpróbálni a beteget ismét krónikus fázisba hozni [16-19].

\section{Krónikus myeloid leukaemia kezelése elörehaladottabb fázisokban}

AZ ELN 2013 kezelési ajánlás különbséget tesz a diagnózis idején észlelt ( „naiv”), illetve a kezelés során kialakult előrehaladottabb fázis között. Az eddigi tapasztalatok szerint a „naiv” akcelerált fázis kimenetele közelebb van a diagnóziskor nagy rizikójúnak tekintett krónikus fázisban levő betegéhez. Ezért ilyen esetben az első választandó kezelés valamelyik TKI, és az allogén őssejtátültetés csak terápiás kudarc esetén jön szóba.

Gyógyszeres kezelési javaslat: $2 \times 400 \mathrm{mg}$ imatinib vagy dasatinib $2 \times 70 \mathrm{mg}$-os vagy $1 \times 100 \mathrm{mg}$-os adagban.

$A$ diagnózis idején elörehaladott fázisban megjelenó CML esetén már kezdetben kötelező a BCR-ABLl mutáció keresése, mert ilyen helyzetben gyakori az imatinibrezisztens mutáció jelenléte. Mutáció jelenlétében első kezelésként nilotinib vagy dasatinib adandó, illetve akcelerált fázisban $2 \times 400 \mathrm{mg}$ nilotinib is szóba jön. Blasztos fázisban csak dasatinibtől várható eredmény.

A korábbi TKI-kezelés során fellépett progresszió esetén bármely, addig még nem alkalmazott TKI a választandó szer, kivéve a T315I-mutációt, amely esetben ponatinib alkalmazandó.

A nilotinib hatásossága blasztos fázisban nem bizonyított!

Allogén össejtátültetés: A megfelelő donor keresését már az előrehaladott fázis diagnózisa után azonnal meg kell kezdeni. Az allogén őssejtátülttetés előtt TKI-kezeléssel megkísérlendő a betegség kedvezőbb fázisba hozása, amelyhez, fóképp blasztos fázis esetén, a TKI mellé sokszor kemoterápia is szükséges.

Az átültetés indikációjának felállításához a beavatkozás kockázata itt is mérlegelendő. Kontrollálatlan, rezisztens blasztos fázisban az őssejtátültetéstől eredmény nem várható, ezért az ellenjavallt [2].

\section{TKI-kezelés elhagyása, terhesség}

Az eddigi ismeretek szerint a TKI-kezelés határozatlan ideig folytatandó. Bár ismert, hogy a mély molekuláris választ $(\mathrm{MR} 4,5)$ mutató betegek egy része terápia elhagyása után is remisszióban marad, de ezek az adatok a legújabb klinikai vizsgálatok keretében születtek, a napi gyakorlatban még nem alkalmazandóak. Azt is megfigyelték, hogy ha a TKI elhagyását a BCR-ABLl molekuláris szint romlása követi, úgy az újrakezdett TKI-kezelés ismét eredményes lehet. A jelenlegi álláspont szerint a TKI-kezelés elhagyása csak jól kontrollált klinikai tanulmány keretében lehetséges. A TKI-kezelés szüneteltetése esetén mindenképpen szorosabb molekuláris monitorozás szükséges.

Terhesség esetén viszont a TKI elhagyása szükséges. Terhesség vállalása lehetőleg legalább 2 éves MMR után javasolt. Amennyiben a terhesség alatt a BCR-ABl szint emelkedni kezd, alfa-interferon adása indokolt.

\section{Bármelyik fázisú CML egyéb kezelése a TKI-érában}

A radotinib egy további TKI, amelyet Koreában alkalmaznak.

Interferon-alfa (rekombináns): Alkalmazási módja a szubkután injekció, amely rekombináns interferon-alfát tartalmaz. Kezdő adagja napi 3-5 millió $\mathrm{NE} / \mathrm{m}^{2}$, amely napi 9-10 millió NE-re emelhető a hematológiai és citogenetikai válaszhoz igazítva. Teljes citogenetikai remiszszióban fenntartó kezelésként a dózis napi 3 millió NE lehet, és a gyakoriság csökkenthető heti 3-4 alkalomra. Az interferonnal a betegek 10-20\%-ában major citogenetikai válasz érhetố el. A teljes citogenetikai remissziót elérő betegek több mint háromnegyede 10 évnél tovább él. Indikáció: Teljes intolerancia TKI-val szemben, transzplantáció kivihetetlensége, TKI-k kontraindikációja, például terhesség.

Omecetaxin szukcinát: Az FDA befogadta 2 vagy több TKI-val szemben rezisztens krónikus vagy akcelerált fázisú CML kezelésére. Ez a szer nem TKI, szubkután alkalmazandó ciklikus formában.

Cytarabin (AraC): Interferonnal kombinálva a major (komplett és parciális) citogenetikai válasz gyakorisága körülbelül 30\%-os.

A cytarabin szubkután injekció formájában adandó. A kombinációban a szokásos dózis $20 \mathrm{mg} / \mathrm{m}^{2} 10$ napon át havonta. Mellékhatás miatt a betegek legalább egyharmadánál tartósan nem lehetett alkalmazni. Ma már csak kivételes esetben indikált.

Hidroxiurea: Ma már csak citoredukcióra, illetve palliatív kezelésre használjuk.

\section{Prognózis}

A CML kimenetelét egyrészt a diagnózis idején jelen levő tényezők, másrészt a TKI-kezelésre adott válaszok minősége határozza meg. 


\section{Diagnóziskor megállapitott prognosztikus pontrendszer}

A diagnóziskor észlelt tényezókkel a betegek prognosztikus besorolása elvégezhetô. Két besorolásra alkalmas pontrendszert (Sokal és Hasford) a XX. század végén, még a TKI-kezelés rendkívüli eredményességének felfedezése előtt írtak le. A Sokal-pontérték kiszámításánál a beteg korát, a lépnagyságot, a thrombocyta- és a blasztszámot veszik figyelembe (www.roc.se/sokal.asp), míg a Hasford-, más néven Euro-pontérték kiszámításánál a fentiek mellett a periférián számolt bazofilek és eozinofilek számát is beépítették a formulába (www.pharmacoepi.de/cmlscore.cgi). (A prognosztikus pontrendszer megalkotásának alapját a Sokal-rendszerben a krónikus és az akcelerált fázisban levő betegek értékelése, míg a Hasford-rendszerben csak a krónikus fázisban levő betegek értékelése képezte.) Mindkét pontrendszerrel a prognózis szempontjából 3 csoport állítható fel: rossz, közepes és jó prognózissal. A TKI-val kezelt betegeken szerzett adatok alapján került felállításra a harmadik rizikópontérték, az Eutos-score 2011-ben, amely formula a lépnagyságon és a bazofilek számán alapszik (http:// www.leukemia-net.org/content/leukemias/cml/eutos_score/index_eng.html). Ezzel a pontrendszerrel két, (nagy és kis) rizikójú csoportot különböztetnek meg. A beteg várható túlélését a prognosztikus csoportba sorolása segít előre jelezni. Nem eldöntött még, hogy erre melyik pontrendszer a legalkalmasabb. Egyelöre úgy látszik, hogy csak a nagy rizikójú csoportba való tartozásnak van szerepe a kimenetel szempontjából. A nagy rizikójú betegek túlélése kedvezótlenebb, mint a kis rizikójúaké. Ha a TKI-kezelés optimális választ eredményezett, akkor az Eutos prognosztikus score, amelyet még a beteg TKI-kezelése előtt határoztak meg, a betegség kimenetelét már nem befolyásolja. Prognózis szempontjából figyelmeztető jel a Ph+-sejtekben a diagnózis idején észlelt kromoszóma-rendellenesség.

Egyéb tényezők, például génexpressziós profil, TKI-val kapcsolatos polimorfizmusok vagy más biológiai markerek (OCTl) prognosztikus szerepét még vizsgálják.

\section{A TKI-kezelésve adott válasszal kapcsolatos prognosztikus tényezők}

Az optimális terápiás válasz kedvező progressziómentes túlélést jósol. A 12 hónapos TKI-kezelés során elért komplett citogenetikai válasz, illetve remisszió (CCR) és major molekuláris válasz (MR 3,0, MMR) szignifikánsan hosszabb túlélést jelent. A legújabb vizsgálatok szerint a korai molekuláris választ ( 3 hónapos TKI-kezelés végén BCR-ABLl szint $<10 \%)$ mutató betegek hosszú távú kedvező kimenetele szignifikánsan jobb.

A citogenetikai és molekuláris válasz elvesztése, vagy a kezelés során bekövetkezett transzformáció, vagy a Ph+ sejtben jelentkező klonális evolúció kedvezőtlen kimenetelt vetít előre. Kedvezőtlen kimenetel várható akkor is, ha TKI-rezisztens BCR-ABLl kinázdomén-mutáció jelenik meg. Figyelmeztető jel, ha TKI-kezelés alatt a Phnegatív klónban kromoszómaabnormalitás lép fel.

$\mathrm{Az}$ imatinibrezisztens beteg második generációs TKIkezelésénél kedvezőtlen jel, ha az első három hónapban semmiféle citogenetikai válasz nincs, illetve ha 6 hónap után nincs legalább minimális citogenetikai válasz.

Az első vonalban adott imatinibkezeléshez hasonlóan a második vonalbeli 2 . generációs TKI-kezelés során megjelenő BCR-ABLl kinázdomén-mutáció megjelenése, illetve annak a TKI-kkal szembeni rezisztenciája prognosztikus jelentőségú $[2,5,7]$.

Anyagi támogatás: A közlemény megírásához a szerzők anyagi támogatásban nem részesültek.

Szerzői munkamegosztás: A közlemény megírásában valamennyi szerző részt vett, panel formájában konszenzust létrehozva a krónikus myeloid leukaemia hazánkban alkalmazható korszerú diagnosztikájának és terápiájának meghatározására. A végleges kézirat formai szerkesztésében részt vett: $\mathrm{D}$. J. és $\mathrm{P}$. A. A cikk végleges változatát valamennyi szerző elolvasta és jóváhagyta.

Érdekeltségek: A szerző́knek nincsenek érdekeltségeik.

\section{Irodalom}

[1] Vardiman, J. W., Melo, J. V., Baccarani, M., et al.: Chronic myelogenous leukaemia, BCR-ABLl positive. In: Swerdlow, S. H., Campo, E., Harris, N. L., et al. (eds.): WHO classification of tumours of haematopoietic and lymphoid tissues, 4th edition. IARC Press, Lyon, 2008.

[2] Baccarani, M., Deininger, M. W., Rosti, G., et al.: European Leukemia Net recommendations for the management of chronic myeloid leukemia: 2013. Blood, 2013, 122(6), 872-884.

[3] Financial protocol for the treatment of chronic myeloid leukemia. [A krónikus myeloid leukaemia kezelésének finanszírozási eljárásrendje.] Magyar Közlöny, 2014, (11), 1715-1722. [Hungarian]

[4] O'Brien, S. G., Guilhot, F., Larson, R. A., et al.: Imatinib compared with interferon and low-dose cytarabine for newly diagnosed chronic-phase chronic myeloid leukemia. N. Engl. J. Med., 2003, 348(11), 994-1004.

[5] Hughes, T. P., Hochhaus, A., Brandford, S., et al.: Long-term prognostic significance of early molecular response to imatinib in newly diagnosed chronic myeloid leukemia: an analysis from the International Randomized Study of Interferon and STI571 (IRIS). Blood, 2010, 116(19), 3758-3765.

[6] Jabbour, E., Hochbaus, A., Cortes, J., et al.: Choosing the best treatment strategy for chronic myeloid leukemia patients resistant to imatinib: weighing the efficacy and safety of individual drugs with BCR-ABL mutations and patient history. Leukemia, 2010, 24(1), 6-12.

[7] Hughes, T. P., Saglio, G., Kantarjian, H. M., et al.: Early molecular response predicts outcomes in patients with chronic myeloid leukemia in chronic phase treated with frontline nilotinib or imatinib. Blood, 2014, 123(9), 1353-1360.

[8] Rosti, G., Palandri, F., Castagnetti, F., et al.: Nilotinib for the frontline treatment of $\mathrm{Ph}(+)$ chronic myeloid leukemia. Blood, 2009, $114(24), 4933-4938$. 
[9] Larson, R. A., Hochhaus, A., Hughes, T. P., et al.: Nilotinib vs imatinib in patients with newly diagnosed Philadelphia chromosome-positive chronic myeloid leukemia in chronic phase: ENESTnd 3-year follow-up. Leukemia, 2012, 26(10), 21972203.

[10] Jabbour, E., Kantarjian, H. M., Saglio, G., et al.: Early response with dasatinib or imatinib in chronic myeloid leukemia: 3-year follow-up from a randomized phase 3 trial (DASISION). Blood, 2014, 123(4), 494-500.

[11] Valent, P., Hadzijusufovic, E., Schernthaner, G. H., et al.: Vascular safety issues in CML patients treated with BCR-ABLl kinase inhibitors. Blood, 2015, 125(6), 901-906.

[12] Breccia, M., Molica, M., Zacheo, I., et al.: Application of systematic coronary risk evaluation chart to identify chronic myeloid leukemia patients at risk of cardiovascular diseases during nilotinib treatment. Ann. Hematol., 2015, 94(3), 393-397.

[13] Kim, T. D., le Coutre, P., Schwarz, M., et al.: Clinical cardiac safety profile of nilotinib. Haematologica, 2012, 97(6), 883-889.

[14] Douxfils, J., Haguet, H., Mullier, F., et al.: Association between BCR-ABL tyrosine kinase inhibitors for chronic myeloid leukemia and cardiovascular events, major molecular response, and overall survival: A systematic review and meta-analysis. JAMA Oncol., 2016, 2(5), 625-632.

[15] Moslehi, J. J., Deininger, M.: Tyrosine kinase inhibitor-associated cardiovascular toxicity in chronic myeloid leukemia. J. Clin. Oncol., 2015, 33(35), 4210-4218.
[16] Sorror, M. L., Martin, P. J., Storb, R. F., et al.: Pre-transplant comorbidities predict severity of acute graft-versus-host disease and subsequent mortality. Blood, 2014, 124(2), 287-295.

[17] Gratwobl, A., Hermans, J., Goldman, J. M., et al.: Risk assessment for patients with chronic myeloid leukaemia before allogeneic blood or marrow transplantation. Chronic Leukemia Working Party of the European Group for Blood and Marrow Transplantation. Lancet, 1998, 352(9134), 1087-1092.

[18] Gratwohl, A., Heim, D.: Current role of stem cell transplantation in chronic myeloid leukaemia. Best Pract. Res. Clin. Haematol., $2009,22(3), 431-443$.

[19] Pavlu, J., Apperley, J.: Chronic myeloid leukemia and the myeloproliferative disorders. In: Apperley, J., Carreras, E., Gluckman, E., et al. (eds.): The EBMT Handbook, 6th Edition. Haematopoietic Stem Cell Transplantation. European School of Haematology/Forum Service editoire, Paris, 2012. Revised Edition.

(Demeter Judit dr., Budapest, Korányi Sándor u. 2/a, 1083 e-mail: demjud6@gmail.com)

\title{
MEGHÍVó
}

\section{A Szent János Kórház és Észak-budai Egyesített Kórházak Tudományos Bizottsága valamint a Fül-Orr-Gégészeti és Szájsebészeti Osztálya tisztelettel meghívja az érdeklődőket a következő tudományos ülésére.}

\author{
Időpont: 2016. szeptember 22. (csütörtök) 14.00 óra
}

Helyszín: Szent János Kórház Auditóriuma - 1125 Budapest, Diós árok 1-3. Téma: „Hallás és légúti rehabilitáció, valamint góckérdés: régi problémák újabb megvilágításban”

Üléselnök: Prof. Dr. Jánosi András

\section{Program:}

Prof. Dr. Hirschberg Andor: Mütéti hallásjavítás a kengyel rögzülése esetén

20 perc

Dr. Szalai György: Góckérdés aktualitásai a fül-orr-gégész szemszögéböl

20 perc

Dr. Nagy Eszter, Dr. Katona József: Góckérdés aktualitásai szájsebészeti szemmel

12 perc

Dr. Smehák György, Prof. Dr. Hirschberg Andor: Kétoldali gégefixáltság mütéti kezelése.

12 perc

Arytenoid-laterofixáció

Dr. Almay Krisztina, Dr. Kis Sándor, Dr. Kerepesi Klára: Akut halláscsökkenés diagnosztikai

és kezelési algoritmusa osztályunkon

12 perc

Minden érdeklődőt szeretettel várunk! 